\title{
The problematic recruitment of migrant labor : A relational perspective on the agency of care work managers
}

\section{Olakivi, Antero Olavi}

2020-05

Olakivi , A O 2020 , ' The problematic recruitment of migrant labor : A relational perspective on the agency of care work managers ' , Current Sociology , vol. 68 , no. 3 , pp. 333-352 . https://doi.org/10.1177/00

http://hdl.handle.net/10138/315443

https://doi.org/10.1177/0011392119837319

acceptedVersion

Downloaded from Helda, University of Helsinki institutional repository.

This is an electronic reprint of the original article.

This reprint may differ from the original in pagination and typographic detail.

Please cite the original version. 
This is a pre-copyedited, author-produced version of an article published in Current Sociology. The final version of the article is available online at: https://journals.sagepub.com/doi/10.1177/o011392119837319. When citing the article, please cite the final version.

\title{
The problematic recruitment of migrant labor: A relational perspective on the agency of care work managers
}

\author{
Corresponding author: Antero Olakivi \\ email: antero.olakivi@helsinki.fi
}

\begin{abstract}
Care organizations in northern Europe recruit increasing numbers of migrant workers, but mostly to low-end jobs and especially to old-age care. According to sociological research, employers and managers play a significant but underexamined role in such recruitment. This article examines the roles played by two care work managers who both have responsibilities in recruitment in a public nursing home in Finland. The article examines the managers' work through the lens of their occupational agency. Drawing on Emirbayer's distinction between substantialist and relational sociology, the article adopts a relational perspective on the managers' agency. Opposite to substantialist studies that operate with analytically pre-given entities (such as agents and structures), the article portrays the managers' agency as open to relationally changing interpretations. The analysis demonstrates how the managers' agency in and around recruitment depends on how the recipients of care, migrant workers and their broader political environment are constructed and interpreted. These relationally changing interpretations, the article argues, can serve many functions, including care work managers' impression management in different situations and, ultimately, the recruitment of migrant workers to (precarious) old-age care.
\end{abstract}

Keywords: migrant care workers; recruitment; agency; relational agency; relational sociology 


\section{Introduction}

Care organizations in Finland, as throughout the Western world, increasingly rely on migrant (i.e., foreign-born) workers (e.g., Wrede, 2010). Public debates often present the recruitment of migrant workers to care work as a win-win situation: it serves Western societies and their aging populations, and migrant workers and their need for employment (e.g., Nordberg, 2016; Torres, 2017). As critical sociologists note, however, Western employers typically recruit migrant people to the most precarious jobs on the lowest ladders of organizational hierarchies, especially in old-age care (Adhikari and Melia, 2015). In Helsinki, for instance, the proportion of foreign-born people working as registered or practical nurses increased from 4\% to 11\% between 2004 and 2013. At the same time, the proportion of foreign-born people working as head or ward nurses remained below 1\%. Furthermore, the majority of migrant care workers in Helsinki work in old-age care (Statistics Finland, 2016). Simultaneously, the number of Finland-born workers planning to quit their jobs in old-age care is soaring, not least due to deteriorating working conditions (Kröger et al., 2018).

Critics thus argue that the current recruitment tendencies might serve Western employers' and governments' economic interests more than they serve foreignborn workers: instead of investing in the general quality of care work to attract Finland-born workers, employers recruit migrant people as a compliant workforce willing - or forced - to work in precarious conditions (Näre, 2013; see also Cangiano and Walsh, 2014; Wrede, 2010). The recipients of this care may also feel less than pleased. Not all want to be cared for by allegedly 'cheap' and 'disposable' labor (Shutes and Walsh, 2012). Migrant workers' language proficiency and ability to communicate with the older recipients of care is a further matter of constant concern in debates over social-care provision in Finland (e.g., Näre, 2013; Olakivi, 2013).

Whose interests the above recruitment tendencies serve is thus a matter of controversy. Regarding this controversy and its political management, an interesting but scarcely examined group of actors are the people who actually recruit migrant workers to care employment in Western countries, including employers and their representatives. This lack of research is surprising, since according to existing studies (and common sense), these actors (can) play important roles in recruitment (e.g., Näre, 2013; see also Bloch and McKay, 2015). According to Gallo and Scrinzi (2016: 367), for instance, 'employers' role in driving the demand for foreign-born [care] workers is considered a key issue in social sciences, [but] it remains largely under-researched and undertheorised.' According to Cangiano and Walsh (2014: 373), 'theory on hiring 
migrant [care] workers, particularly in terms of a sociological understanding, is not well developed.' In this article, I offer one theoretical and empirical understanding of the role of employers and their representatives - namely, care work managers and senior professionals in public social-care provision in Finland. The article has three objectives.

First, the article demonstrates how the responsibilities of care work managers in and around recruitment can be productively analyzed through the lens of their occupational agency (and lack of it) - that is, their ability to alter their behavior (Campbell, 2009), make a difference in their environment (Giddens, 1984) and, ultimately, serve specific interests (Meyer and Jepperson, 2000). In addition to the ability of managers to act over structural constraints (Campbell, 2009), the article thus examines their ability to act as agents for others - a dimension of human agency often neglected in sociological research (Shapiro, 2005). Respectively, the article not only asks whether care work managers have agency but also whose interests they serve and whom they are agents for (see Niska, 2015).

Second, as Niska (2015) highlights, both dimensions of agency - agency over (structural constraints) and agency for (specific interests), as she labels them can be examined from different meta-theoretical perspectives. In line with Emirbayer (1997), these perspectives can be termed substantialist and relational. As I will demonstrate, previous research on the recruitment of migrant workers has preferred substantialist meta-theories. It has examined how different things, beings, and entities, such as demographic structures, economic doctrines, or cognitive schemata, affect the practices of recruitment, including the agency of care work managers. A relational framework, in contrast, turns attention to the 'dynamic relations' (Emirbayer, 1997: 281) through which managers' agency receives meanings and significance 'in relation to surrounding persons, places, meanings and events' (Roseneil and Ketokivi, 2016: 149). This article examines these relational processes from a dramaturgical (Goffman, 1959; Hughes, 1984) and micro-constructionist perspective (Burr, 2003). This perspective is especially productive, I argue, when one is analyzing moving targets of interpretive struggle and political controversy, such as the agency of care work managers.

Third, the empirical analysis demonstrates how care work managers' agency is relational to how migrant people and the broader environment of care provision are socially constructed and categorized. From a dramaturgical perspective, the analysis demonstrates how managers can, perhaps routinely, highlight their 
agency for legitimate interests but also mitigate their abilities to act (over structural constraints). This ability to manage diverse and situationally changing impressions is, I argue, functional for care work managers who, in their morally precarious environment (Vanessa May, personal communication, 2018), need to present their worth and value to various audiences, from policymakers and (migrant) care workers to the recipients of care. Ultimately, managers' ability to manage diverse impressions of their occupational agency in front of other actors but also for themselves - can support the increasing recruitment of migrant workers to old-age care in Finland.

\section{Previous insights on the agency of care work managers}

Although agency is a key concept of the sociology discipline (Shapiro, 2005), few studies have focused on employers' or managers' agency in the recruitment of migrant care workers (see also McGovern, 2007). Previous studies have instead identified a plethora of complex, structure-like factors or 'macro-actors' (Callon and Latour, 1981) affecting the processes of recruitment. In addition to demographic structures (i.e., aging populations), studies have identified factors, actors and beings such as gender regimes, welfare systems (Gallo and Scrinzi, 2016) and global capitalism (Williams, 2018) that play contextually varying roles in creating the migrant precariat (Hellgren, 2015) and the 'international division of care work that places the burden for care on the least powerful (immigrant women workers)' (Misra et al., 2006: 318).

At the street-level of care organizations, studies have extracted further things and beings that shape the organization of care work and the recruitment of care workers. Carter (2000), for instance, writes about the New Public Management paradigm, which highlights the economic efficiency of care provision and leaves little room for managers to promote equality in work (see also Dahle and Seeberg, 2013). Some studies, finally, conceive care work managers as actors who have (a degree of) agency and responsibility over current recruitment practices (e.g., Adhikari and Melia, 2015). These studies, however, have a tendency to extract complex psychosocial factors and beings, such as ethnic stereotypes, attitudes and other cognitive schemata, that shape managers' (or employers') behavior as they hire migrant workers to low-end jobs that match poorly with their skills and interests (e.g., Cangiano and Walsh, 2014; Carter, 2000; see also Gallo and Scrinzi, 2016). In many studies, an important role is played by managers' desire for compliant workers and their tendency to perceive migrants as such (Näre, 2013; see also Waldinger and Lichter, 2003). 
What emerges from the theoretically diverse literature is a picture of complex actors, things and beings (from public policies to cultural and cognitive schemata) that shape employers' and managers' work (see also Anderson and Ruhs, 2010). Some studies conceive employers and managers as active, responsible and agential participants who are nonetheless constrained by their internalized psychosocial structures (e.g., stereotypes, motives and attitudes) (e.g., Cangiano and Walsh, 2014; Gallo and Scrinzi, 2016; see also Bloch and McKay, 2015), including their desire for a compliant workforce (Näre, 2013; see also Anderson and Ruhs, 2010; Waldinger and Lichter, 2003). Moreover, employers' and managers' agency seems to serve illegitimate objectives, such as the production of new ethnic hierarchies. From a sociological perspective, these interpretations are entirely valid. For managers themselves, they might be less pleasant. Modern societies generally expect (agential) individuals to serve legitimate interests in a self-reflexive and non-biased manner (Meyer and Jepperson, 2000). In a Nordic country, such as Finland, public sector managers are expected to serve their clients' well-being, not the production of new inequalities (Olakivi and Niska, 2017). In societies such as Finland that promote social equality, the active exploitation of vulnerable people is scarcely an acceptable objective (e.g., Sulkunen, 2010). What the above line of research has not examined are care work managers' contextual means to manage legitimate impressions of their occupational agency. To examine such means, I adopt a relational perspective.

\section{Two perspectives on human agency}

In what follows, I examine care work managers' agency (and non-agency) from a meta-theoretical perspective that Emirbayer (1997) calls relational sociology. In his provocative essay, Emirbayer (1997: 282) argues that the key difference between sociological perspectives is "not "material versus ideal," "structure versus agency," "individual versus society," or any of the other dualisms so often noted; rather, it is the choice between substantialism and relationalism.'

According to Emirbayer (1997), substantialist perspectives highlight the 'selfaction' or, more likely, 'inter-action' of pre-existing things, beings and substances as the premise of scientific inquiry. In respect of care work, one might highlight the 'self-action' of a single entity, such as global capitalism or the complex 'inter-action' of different factors, actors and beings, such as global capitalism, managers' motives and demographic structures. Cangiano and Walsh (2014: 374), for instance, highlight 'multiple factors in the recruitment process.' 'An effective conceptual framework,' for them (2014: 385), 'must take 
into account the complex links between labour market structure and segmentation, employer decision making and state immigration regulations.' In the substantialist framework, scholars often argue over the entities that must be accounted for and perhaps assume that the more entities they extract and complex inter-actions they examine, the more accurate their studies become.

A relational framework, in contrast, turns attention to dynamic, unfolding and ongoing processes that - unlike the substantialist 'inter-actions' of analytically pre-given entities - constitute the entities involved (Emirbayer, 1997). Relational research is not only - or primarily - interested in how things interact. Rather, it examines how things receive meanings in relation to each other (see also Mützel, 2009). From a relational perspective, the agency of care work managers is not a pre-existing substance that is constrained by other preexisting substances, such as public policies and cognitive stereotypes. Instead, the agency of care work managers is a relational construct that receives its particular meanings in relation to other relational constructs (such as public policies and cognitive stereotypes), which also receive their particular meanings in relation to each other. From a relational perspective, it 'makes no sense to envision constituent elements apart from the flows within which they are involved (and vice versa)' (Emirbayer, 1997: 289).

One should not confuse the distinction between substantialism and relationalism with the distinction between agency and structure (Emirbayer, 1997; see also Harré, 2009). Instead, agency and structure can be examined from both relational and substantialist perspectives (Niska, 2015). Substantialist research can examine how agency and structures - such as employers' decisionmaking agency and labor market structures - affect each other. To pursue such an examination, however, substantialist research must conceive agents and structures as pre-given elements of empirical analysis; otherwise, their 'interaction' cannot be examined (Eteläpelto et al., 2013). Relational research, in contrast, begins from a process and moves on to examine how agents and structures come - or do not come - into being in relation to each other within this process (e.g., Fuchs, 2001). In this article, I draw on the relational framework to analyze the interpretive struggle and political controversy over care work managers' agency in and around recruitment.

\section{Empirical case: Care work managers' relational (non-)agency}

Many theoretical perspectives can be used in accordance with relational metatheory. Emirbayer (1997) mentions scholars from Bourdieu and Foucault to 
Latour and Goffman while Niska (2015) continues with Harré's positioning theory and Wetherell's critical discursive psychology. In this article, I draw on dramaturgical sociology, mainly from Goffman (1959) and Hughes (1984), together with what Burr (2003) calls micro-constructionist discourse analysis. These lines of research share a common interest in meaning-making and impression management in face-to-face interaction (Niska, 2015). In a sense, micro-constructionist research has continued dramaturgical studies on facework (Goffman, 1955) or the ways in which actors collectively manage appropriate selves in societal settings, including the 'social drama of work' (Hughes, 1984: 345). Whittle and Mueller (2016) conceive 'agency' and 'structure' as discursive devices that actors can employ in such a drama. Niska (2015), in turn, has studied the adoption of an external principal - a party whose interests the actor claims to serve - as a way for people to construct legitimate agency.

In the analysis and conclusions, I contrast the relational, dramaturgical and micro-constructionist reading with substantialist and macro-constructionist interpretations. My aim is to demonstrate how different theoretical frameworks enable different interpretations of care work managers' activities in and around recruitment. The difference between what Burr (2003) calls micro- and macroconstructionist research is twofold. First, macro-constructionism (e.g., some forms of poststructuralist discourse analysis) generally highlights the power of discursive systems in historical and enduring processes of knowledge production. Micro-constructionism, in contrast, examines actors' collaborative, discursive activities in immediate and local dramaturgical situations (see also Hacking, 2004). Second, for macro-constructionism, discursive systems mainly serve societal power relations, such as the production of class relations and social inequalities (see Burr, 2003; see also Zanoni and Janssens, 2004). For micro-constructionism, discourse-users mainly use discourse to serve their own agenda, such as their appropriate self-presentation in face-to-face interaction (Burr, 2003; see also Niska, 2015). Eventually, however, appropriate selfpresentation can also facilitate broader societal transformations if it legitimates otherwise controversial lines of action (Olakivi, 2018).

This study examines impression management, in which care work managers construct their agency - and non-agency - over particular structures and for specific interests. Evidently, care work managers inhabit a difficult position in Finland. In line with the previously cited academic literature, managers might claim to have little agency in recruitment (see also Anderson and Ruhs, 2010). To a degree, this interpretation might serve their self-presentations: they would 
not be responsible for their actions' unwanted consequences, such as the development of new divisions of labor. Having no agency at all, however, might also be a problematic impression for care work managers, especially in contemporary societies where personal agency is almost a 'cultural imperative' (Reynolds et al., 2007: 348) and a 'measure of human dignity' (Sulkunen, 2010: 503). At least in northern Europe, public officials, including care work managers, are expected to appear as reflexive and transformative agents who make improvements happen in their local environment (Olakivi and Niska, 2017). The question I ask in relation to this is how can care work managers portray such agency in the recruitment of migrant labor?

\section{Methods and materials}

The following analysis is based on semi-structured interviews conducted as part of a larger research project from 2011 to 2013. The project, titled 'Shaping of Occupational Subjectivities of Migrant Care Workers: A Multi-sited Analysis of Glocalising Elderly Care,' was funded by the Academy of Finland (\#251239). The original data consisted of 14 interviews with care work managers (i.e., middle managers and senior professionals) in public social-care provision in Helsinki. The following analysis examines two of the interviews in detail. The first interviewee, 'Julia,' was a ward nurse in a municipal nursing home; she was officially responsible for recruiting temporary workers and fixed-term substitutes, mainly from the domestic labor market. The second interviewee, 'Nina,' was a head nurse in the same nursing home; she was officially responsible for enlisting permanent staff, mainly from the domestic labor market. Circa one third of their staff members had a foreign background, mainly from the former Soviet republics, sub-Saharan Africa or South-East Asia. The residents in the nursing home were all born in Finland.

The aim of the analysis is not to capture all forms of agency construction but to tease out patterns in the potential self-presentations of care work managers. I have deliberately chosen these two interviews to demonstrate how even the same managers' activities can receive varying meanings, depending on the situational requirements. These meanings are by no means unique to the two interviews. Similar interpretations about current recruitment tendencies circulate in public debates in Finland and elsewhere (e.g., Näre and Nordberg, 2016; Nordberg, 2016; Torres, 2017).

I analyze the two interviews as embodied, social and dramaturgical situations in which the interviewees faced a practical problem (Olakivi, 2018): how to 
manage morally acceptable yet convincing impressions of their occupational activities and, ultimately, themselves as respectable people (Lamont and Swidler, 2014)? In the interviews, the participants' agency is relational to various stakeholders, such as migrant and indigenous care workers, who are not present but offer resources for the participants' discursive performances.

The interviews contained several themes, ranging from ethnic diversity and the recruitment of migrant workers to the future of social care in Finland (see also Olakivi, 2018). The interviews were transcribed verbatim (see Appendix 1 for transcription notation). The extracts provided below are translated by the author with some details omitted to protect the participants' anonymity.

As Hughes (1984: 508) notes, a research interview, as a site of social interaction, 'is not merely a tool of sociology but part of its very subject matter.' Analyzing interviews only makes sense if interview interaction is assumed to follow certain patterns (Burr, 2003). In what follows, I focus on the relational resources (Nikander, 2012; see also Lamont and Swidler, 2014) that the participants with the interviewers' support - use to craft positive impressions of themselves and their work. Although the analysis focuses on interview interactions with the two participants, other care work managers can (or must) use similar resources in other contexts, including interactions with migrant and Finnish-born employees, older clients and their relatives, their own superiors, etc. The analysis is led by the following question: With what relational resources are managers able to manage positive impressions of the recruitment of migrant workers in a cultural context where such recruitment is politically contested?

\section{Analysis}

\section{Julia}

Julia, a ward nurse in a municipal nursing home, was interviewed in 2011 (by the author). Her main job, as she stated, was to sustain the functions of the ward and 'ensure there are capable staff members' who can 'carry out highquality care.' She talked extensively about difficulties in finding employees and simultaneously highlighted her personal agency as a manager who has 'created quite a good network of temps.' Many of the temps were of migrant backgrounds. When I invited Julia to think about possible differences between migrant and Finland-born workers, she drew on a common stereotype of African workers. 
JULIA: I've noted that if they come from these African countries, like many of our care workers do, or those who work here as temps, somehow you can see the kind of respect towards the work [in them]. They do it extremely well and with good quality, and they accept any assignments whatsoever. Somehow, they don't make a fuss about anything. Maybe it's because they're accustomed to working more. And they're always ready to yield. That's what I've noticed, at least. [...] There can of course be the language problem, that they're not that good in Finnish. But then again, I've noticed that they're very reliable employees. [...] They've come here to work for the residents.

In the above, Julia answers my request by defining migrant workers, African workers in particular, as good workers for both clients and managers: migrants do their work 'with good quality' and 'are always ready to yield' (see also Näre, 2013). In the extract, Julia delicately avoids presenting herself as a manager who is actively - and agentially - asking migrants to be flexible or submissive. Instead of being objects of her managerial control, she presents migrant workers as inherently motivated agents and herself as a somewhat passive observer who has merely 'noticed' their superior ethics: 'They have come here to work for the residents.' While 'there can be the language problem,' this problem is evidently a minor one. As Julia moves on to clarify, the clients and their relatives - the main principals of Julia's work - rarely complain.

JULIA: They do understand the challenge, that it's difficult to get people with [the appropriate language skills]. And quite often the relatives give quite okay feedback about how our migrant background workers have taken very good care of their relatives. And often they can, for some reason, take good care of the most challenging residents; it may be their kind of calmness that works.

In the preceding extract, Julia enables two interpretations of the recruitment of migrant workers. First, it is a structural necessity. Finding people is difficult. Second, recruiting migrants serves older clients and their relatives. Migrants take good care of the residents.

Many things are happening in the preceding extracts that can also be understood from diverse perspectives. From a substantialist perspective, a critical interpreter might focus on Julia's stereotypical and perhaps essentialist perceptions of migrant (and African) workers. In a sense, Julia conceives migrant workers as members of their cultural or national groups, rather than 
members of a professional community. It is their flexibility, respect and calmness as psychological traits rather than professional skills that Julia highlights and values. A substantialist scholar might assume that these perceptions can - together with other factors - affect Julia's preferences and behavior in hiring (e.g., Carter, 2000; see also Anderson and Ruhs, 2010; Gallo and Scrinzi, 2016). From a macro-constructionist perspective, the above perceptions may not affect Julia's behavior in hiring, but, nonetheless, they serve societal power relations: they construct migrant workers as natural carers and reduce their ability to be recognized as educated professionals who can achieve higher positions in the organizational hierarchy (see Dahle and Seeberg, 2013; Zanoni and Janssens, 2004).

A dramaturgical and micro-constructionist perspective focuses on the ways in which the preceding categorizations serve the self-presentation of Julia in the context of a morally challenging interview (and perhaps other similar encounters in and around her work). By drawing on specific impressions of migrant workers (as relational resources), Julia can construct positive impressions of her own agency as a person who recruits migrant people. Her positive agency is relational to how migrant workers are constructed: they are not passive objects of her control but active, self-directed and motivated agents; they are not people who lack something (e.g., language proficiency) but people with a special asset (e.g., calmness, superior work ethics). In another context, Julia might describe migrant workers in a different way. Indeed, when it comes to international recruitment, Julia draws on a different set of relational resources.

INTERVIEWER: What do you think about international recruitment? [...] Some private care companies do it already, but what would you think if the City of Helsinki would start doing it?

JULIA: I'm against it, as a matter of fact. They do recruit a lot of nurses from the Philippines, and it's great that they can be offered jobs. But in my opinion, we should start to think... There are so many nurses without a job in Finland. [...] In my opinion, hiring them should be the priority. It cannot be the solution that the kind of cheaper workforce is recruited from the Philippines because they're willing to work for these low wages. And there would be the language issue again. In my opinion, the wage issue should really be taken forward.

While the recruitment of already arrived migrants seemed to serve the interests of all relevant parties, international recruitment might, according to Julia, serve 
migrant workers but not unemployed nurses in Finland - a new category of principals that Julia calls into being. The language issue, mitigated in the previous extracts, is invoked again to argue against international recruitment. In short, a different impression of 'the migrant worker' is constructed. An internationally recruited migrant worker is cheap labor, willing to work for poor wages, whereas a domestically recruited migrant worker is a skillful and inherently motivated agent for older clients. By drawing on these distinctions, Julia can construct her own domestic recruitment practice as a positive alternative to a negative scenario (i.e., international recruitment) suggested by the interviewer.

The preceding account by Julia also contests the dominant discourse (in the Finnish media) that presents migrant workers as a solution to a structural problem (i.e., the lack of workers) created by the aging population (Näre and Nordberg, 2016). The main problem for Julia is not the aging population but the poor wages in care work that do not attract domestic professionals. International recruitment does not solve this problem. To Julia, as she moves on to explain, problems in public old-age care are caused by (economically oriented) policymakers who promise to increase resources in care but do not keep their promises. When diagnosed in this way, Julia has little responsibility over problems in care work but also little agency in solving them.

After highlighting the agency of public policies (see also Anderson and Ruhs, 2010), however, Julia begins to formulate an alternative interpretation that enables a small degree of agency for her and her colleagues. In this interpretation, there is an urgent need for action: 'The average age is going up [...] and there will probably be more people with multiple illnesses; something needs to happen.' Moreover, 'the role of these migrant nurses will be pretty important in eldercare in future' and, according to Julia, 'they should be warmly welcomed.' Beyond having a welcoming attitude, Julia promotes reductions in language requirements in care work.

JULIA: I wonder how long we can always exclude certain applicants and just say that "we cannot [employ her] because she doesn't know [the language]"; maybe we should start to widen up the way we think and simply employ the workers who know what they do.

INTERVIEWER: Do you think the importance of language has been overemphasized perhaps?

JULIA: Sometimes I feel that it is, because, at least in here, we never receive such feedback from the relatives; it has never been brought up as a 
problem in the discussions. The biggest problem that comes up is the lack of time. [...] It is not the language. Of course, I do understand that it's [important.] [...] But if things continue the way they are, then I think we should loosen up the [language] requirements and not be so awfully strict in respect to certain applicants. We should somehow collect all the resources together and see that whatever country we're from, it's certain that, as nurses, we all serve the same purpose and work here for the older people. That's the way of thinking that should be taken forward.

In the preceding extract, Julia constructs a distinction between two different motives or principles. Care work managers (and care workers) can act as agents for older people (and their relatives) or as agents for bureaucratic rules and requirements. Naturally, when categorized this way, the only legitimate choice is the former. Similarly, care workers can either know the language or know what to do (see also Olakivi, 2013); again, the latter alternative is easily preferable. Although Julia might not have agency over the legal language requirements in Finland, she has the relational resources to present her welcoming attitude (and her current recruitment practice) as both a structural necessity and a way to serve older Finns. (Correspondingly, Julia can keep on hiring temporary workers who, according to her, do not know any language that she speaks.)

In the above extract, Julia finally draws on a novel relational resource to present her recruitment preferences and practices in a positive way: an international community of professional nurses. While Julia formerly presented (domestically recruited) migrant workers as members of their national and cultural groups (and consequently virtuous and motivated care workers), she now presents them as members of this international community of nurses (and consequently virtuous and motivated care workers).

From a substantialist perspective, one might examine Julia's conceptions of migrant workers and language requirements in care work as cognitive schemata that, ultimately, affect her actions in hiring. As the above extracts demonstrate, however, Julia can present different conceptions of both migrant workers and language requirements in care work. In the previous extract, language requirements were a reason for Julia to oppose international recruitment. In the above extract, reducing language requirements is both a structural necessity and a means to serve older people (if not, ultimately, all actors in tandem). A substantial scholar might continue the analysis by asking whether some of the above controversial conceptions over migrant workers and language requirements have more power over Julia's behavior than others. 
A relational, micro-constructionist and dramaturgical standpoint enables an alternative line of analysis. From this perspective, the above extracts demonstrate how Julia can draw on multiple, situationally changing resources to justify her own domestic activities in and around recruitment. In a morally challenging interview setting and a politically challenging organizational environment, such a multiplicity of resources for positive self-presentation is assumedly a pragmatic asset. In different situations, Julia can draw on different relational resources to justify the increasing recruitment of migrant workers to old-age care.

\section{Nina}

Nina, a head nurse in the same nursing home as Julia, was interviewed in 2011 (by my colleague). In the beginning of the interview, Nina defines human resource management and recruitment as her main jobs. She is primarily responsible for enlisting permanent staff. She presents recruitment as the most 'challenging' part of her work (and thus highlights her responsibility and agency in and around recruitment). Her job, as she presents it, is also to 'support' and 'motivate' her subordinate ward nurses in 'the grass-roots level of recruitment.' Nina, like Julia, has the relational resources to present the recruitment of migrants as a positive tendency.

INTERVIEWER: If we talk about your foreign and Finnish background [workers], do you see any differences in them as employees?

NINA: I cannot divide them in two. There're good and there're challenging Finns as well as... it's not the nationality that makes a difference. But I think... [...] they [i.e., migrants] are probably kinder and easier for a manager. And, one might say friendlier. But I wouldn't say the Finns are... I can't divide them in two. It's not the nationality.

INTERVIEWER: Yeah, could it be that this kindness is not only a good thing?

NINA: Not necessarily. Then you might lack the kind of critical and analytical depth, and the kind of development of your own actions. There might be less of that. I don't know.

INTERVIEWER: What do you think about the fact that there are people of different backgrounds working here?

NINA: Well, I think it enriches this eldercare work, and I think we Finns have a lot to learn from other cultures. Our eldercare is not the best of all. We could learn a lot about the sort of respect towards older people and 
older age from other parts of the world. I would be very open-minded and welcoming of all new perspectives.

In the above, Nina looks at the differences between Finnish and migrant background workers from different perspectives, trying to avoid impressions of stereotypical thinking - although she is perhaps invited to perform such thinking by the interviewer. The principal that either benefits or suffers from the increasing recruitment of migrant workers varies during her account. First, it is the manager who might receive easier employees (see also Näre, 2013). Second, it is the Finns who might receive new perspectives. Again, migrants are presented as members of their ethnic or national cultures rather than a professional community. However, a novel psychosocial distinction between migrant background as an asset (e.g., 'new perspectives') and a hindrance (e.g., 'lack of critical depth') is called into being by Nina and the interviewer. Consequently, Nina (like Julia) can create some distance from the (potentially harmful) impression of herself as a manager who values submissive workers over self-directive workers (see also Olakivi and Niska, 2017). Although Nina demonstrates her open-mindedness and a welcoming attitude, she aligns with Julia in being against international recruitment.

INTERVIEWER: What do you think about international recruitment, that people are recruited directly from abroad? What is your...

NINA: Well I think it's not... It has so many challenges in respect to language proficiency and culture, that I wouldn't go there. And because we've already been able to hire [foreign-born] people who are in Finland quite okay. It would then require a huge amount of orienting work.

Nina's argument against international recruitment is somewhat similar to Julia's argument. They are both concerned with the recruited workers' language proficiency (along with challenges in respect of 'culture'). Interestingly - and, to some extent, in contrast to what has been discussed above - the City of Helsinki had a project of international recruitment in 2007-2008. In total, 67 Ingrian Finns, mainly Russian nationals of Finnish descent, were recruited to Helsinki from across the eastern border, mainly to work as cleaners, special needs assistants and practical nurses (Näre, 2012). When this project comes up in the interview, Nina describes it as difficult but successful.

INTERVIEWER: How did this Ingrian project come out, in your opinion? Because it was international.... 
NINA: The outcome was good, but the road was extremely long, awfully long and very hard also for the students [who came to Finland]. But the outcome was good. The nurses who came here were extremely good, and many stayed working for us.

Two issues are worth noting in the above extracts. First, although Nina highlights her concern over the language proficiency of internationally recruited workers, when it comes to past actions of her own employer (i.e., the City of Helsinki), she presents these actions positively. The project was hard, but the outcomes were good. By highlighting the positive outcomes, Nina can present the past project as a success story - and protect her employers 'face' - yet simultaneously prefer domestic recruitment (and thus her own recruitment practice) in future.

Second, the problems that Nina identifies in international recruitment are also problems for the migrants themselves: the road was also 'long and very hard' for the recruited students. Thus, Nina constructs migrants as principals whose interests matter and are not self-evidently served in international recruitment. At the end of the interview, Nina further discusses the interests that (domestic) recruitment and the development of care work in general should serve.

INTERVIEWER: What about the future of eldercare in Finland? How do you see the future and then the role of immigrants in eldercare?

NINA: Well I suppose the future of eldercare, I hope the kind of forwardlooking approach [...] that we have here [in this workplace], I hope it'll spread to other places. [...] But the resources are scarce, and there is always the danger that if we start doing things in the cheapest way, then quality is so poor. [...]

INTERVIEWER: Then what about immigrants?

NINA: Immigrants. The way I see it, there is an awful lack of workforce in this field of work, and it's only getting worse. Soon we'll have a real [issue]. Where are we getting employees from?! And in my view, people of migrant backgrounds are one of those resources, and many [of them] are interested. This is a really nice workplace. A nice workplace. And it's not the nationality. It's a nice workplace [also] for a Finn. There are many opportunities to develop and... No opportunities to get a very good salary, but opportunities to proceed and develop the work and so on. I see this as an important field in the future, and immigrants are, you might almost say, indispensable for us so that we can keep the wheels rolling in eldercare. 
At first, Nina takes quite an instrumental (and non-agential) approach to the recruitment of migrant workers: migrants are an indispensable resource in the context of structural necessity. Second, however, she creates a different impression of the recruitment practice as serving the interests of the (domestically) recruited migrants: many of them are interested and can be offered good jobs, or at least jobs. Apparently, she lacks the resources to construct care work as an ideal job (to anybody), but to a migrant job-seeker, perhaps one with few better alternatives, it is a decent job (Torres, 2017; Waldinger and Lichter, 2003; Zanoni and Janssens, 2004). An impression of a win-win situation is managed, though not without struggle. The main reason for recruiting migrants is the alarming structural necessity and 'our' interests (see also Torres, 2017): migrants are indispensable for us.

The above extract can again be interpreted from diverse perspectives. From a macro-constructionist perspective, one might argue that by constructing 'us' (e.g., the Finnish people or eldercare system) as the main principal of recruitment, the preceding discourse plays down the interests of migrant workers which might, in turn, increase their societal marginalization (see also Zanoni and Janssens, 2004). From a substantialist (e.g., a cognitivist) perspective, one might further assume that Nina, as a manager, is driven by an instrumental, economic and nationalist motive that affects her behavior in hiring.

From a micro-constructionist and dramaturgical perspective, the preceding extracts show how managers' discursive space is morally precarious (Vanessa May, personal communication, 2018): managers' ability to appear as proper agents is under constant threat (see also Sulkunen, 2010). However, the above extracts also demonstrate how managers can find at least provisional ways to legitimate the growing recruitment of migrant workers to old age care. Presenting migrant workers as agents driven by motives other than a good salary works as a relational resource in such management of legitimate impressions. Nina cannot claim to be offering significant monetary rewards, but she can still (try to) present herself as an agent who serves migrant workers especially if the migrants are domestically recruited.

\section{Discussion and conclusions}

According to Gallo and Scrinzi (2016), employers play an important but underexamined role in the recruitment of foreign-born care workers in Europe. This article has examined the role of employers, and specifically, care work managers, 
through the lens of their occupational agency. The article has examined managers' agency over structural constraints and for specific interests from the perspective of relational sociology.

Previously, substantialist sociology has portrayed managers' agency as constrained by various things, beings and essences. Studies have highlighted the power of external factors, such as demographic structures, as well as internal and psychological factors, such as racial stereotypes and attitudes in the recruitment of migrant workers. From a relational perspective, managers' agency - and the lack of it - is a matter of constant construction. Moreover, from a dramaturgical and micro-constructionist perspective, managers' agency is constructed in face-to-face interaction. In this study, I have examined care work managers' agency construction in interview interaction.

At times, the interviewed managers highlighted their personal (albeit limited) agency in and around recruitment. At other times, they highlighted the power of external factors, actors and beings, such as policymakers and demographic structures. Highlighting external factors can be a pragmatic pattern for managers' self-presentation; in these self-presentations, managers are not personally responsible if their activities are criticized for serving illegitimate interests.

The interests that managers serve, however, are equally open to interpretive struggle. In one interpretation, the current recruitment tendencies represent managers' means to acquire a compliant workforce and provide care without improving care workers' wages. In alternative interpretations, the same recruitment tendencies are managers' means to improve the quality of care and help self-directive, motivated and agential migrants find the jobs they authentically want. The first interpretation makes managers' agency seem socially questionable, while the latter interpretations construct managers as agents for both migrant job-seekers and (Finnish) recipients of care.

The participants had two key patterns for constructing morally appealing impressions of their own agency in recruitment. This is the first main conclusion of the article. The first pattern was to construct a sharp distinction between domestic and international recruitment. Evidently, framing international recruitment as a practice that violates the interests of nurses in Finland, international job-seekers or (Finnish) recipients of care is a pragmatic resource with which care managers can construct domestic recruitment as a desirable alternative. From a micro-constructionist perspective, such a framing 
was understandable in the dramaturgical setting of the interview. After all, the interviewees were engaged in domestic, not international, recruitment.

The second pattern of constructing the recruitment of migrant workers as a morally appealing tendency was to construct migrant workers as capable, selfdirective and inherently motivated (instead of externally controlled or compelled) agents for (Finnish) recipients of care. Significantly, the interviewed managers were able to achieve such constructions in different ways by constructing migrants as professional nurses or ethnic others. This is the second main conclusion of the article.

A macro-constructionist perspective might argue that constructing migrant workers as professional nurses serves migrant workers, while constructing migrant workers as ethnic others does not (see also Olakivi and Niska, 2016). As Näre (2013: 76) notes, based on research interviews with care work managers and employers, 'employers' misrecognition of migrants as different to Finns reinforces the social subjugation of migrants in the work places.' In such practices of distorted diversity management, according to Zanoni and Janssens (2004: 70), minority employees are 'discursively denied full subjectivity and agency.' From a macro-constructionist perspective, these interpretations are entirely valid (see also Olakivi and Niska, 2016). From a dramaturgical and micro-constructionist perspective, however, these interpretations may overestimate the power of certain discourses (e.g., ethnic othering) and underestimate the particular, flexible and contextual ways in which people use language (and different discourses) in situated encounters, including research interviews (see also Olakivi, 2013).

From a dramaturgical and micro-constructionist perspective, both of the preceding patterns - that is, presenting migrants as ethnic others and professional nurses - can serve the same interactional function: they help managers present themselves as appropriate agents for both migrant jobseekers and (Finnish) recipients of care. Consequently, both of the preceding discursive patterns - that is, not only ethnic othering - can serve the same organizational function: they support the recruitment of migrant workers to precarious old-age care.

Managers, of course, are not the only people making sense of their work. Other actors can always question, challenge and reinterpret their positive selfpresentations (see also Olakivi, 2018). Regardless of managers' own selfpresentations, other actors can conceive managers as agents for their employers' 
economic interests, ethnic hierarchies or new divisions of labor. Future research would gain significantly from studying the situated reception of managers' selfpresentations across dramaturgical settings, including managers' encounters with migrant workers and recipients of care.

This article has demonstrated how employers and managers, as competent members of society (see Garfinkel, 1967), can use situationally changing relational resources to manage affectively appealing impressions of their activities. Managers can present personal agency and non-agency, highlight and mitigate language requirements in care work, construct migrant workers in different ways, etc. This brings me to the concluding argument of this article.

The agency of managers in the recruitment of foreign-born care workers is, I argue, an important topic of research. In contrast to substantialist sociology, however, one does not need to understand such agency as a result of the complex 'inter-action' of analytically pre-given, sociological or psychological entities. In fact, it may be care work managers' socially embedded ability to manage alternative, situationally changing impressions of the involved entities and their own activities (see also Näre, 2013) - including impressions of nonagency - that, in part, enables them to participate in the politically contentious hiring of migrant workers to precarious jobs. If future sociology is to understand these aspects of recruitment, even to build a 'theory on hiring migrant workers' (Cangiano and Walsh, 2014: 373), it must accept that in such theory, the agency of employers and managers is a moving target: it can be interpreted in competing ways by, for instance, sociologists, policymakers, care work managers and recipients of care. When approaching such targets, relational sociology is a productive framework.

\section{Acknowledgements}

I am grateful to the fourteen interviewees, especially Julia and Nina, for making the study possible. I also thank Lena Näre, Sofia Söderberg and Miika Saukkonen for their invaluable efforts in the data collection, and Davina Allen, Bridget Anderson, Erna Bodström, Vanessa May, Pirjo Nikander, Miira Niska, Lena Näre, Sanna Rönkä, Sirpa Wrede, the journal editors, and the anonymous reviewers for their insightful comments on (earlier versions of) the article.

\section{Funding information}


I received funding from the Finnish Cultural Foundation, the Finnish Work Environment Fund, the Academy of Finland (\#251239) and the Centre of Excellence in Research on Ageing and Care (RG 3 Migration, Care and Ageing, \#312310).

\section{Appendix 1: transcription notation}

[...] Three dots in square brackets: a short, omitted sequence

[word] Square brackets: comments or clarifications made by the author

\section{References}

Adhikari R and Melia KM (2015) The (mis)management of migrant nurses in the UK: a sociological study. Journal of Nursing Management 23(3): 359-367.

Anderson B and Ruhs M (2010) Migrant workers: who needs them? A framework for the analysis of staff shortages, immigration and public policy. In: Ruhs M and Anderson B (eds) Who needs migrant workers? Labour shortages, immigration, and public policy. Oxford: Oxford University Press, pp. 15-52.

Bloch A and McKay S (2015) Employment, social networks and undocumented migrants: The employer perspective. Sociology 49(1): 38-55.

Burr V 2003 Social constructionism. London: Routledge.

Callon M and Latour B (1981) Unscrewing the big Leviathan: how actors macrostructure reality and how sociologists help them to do so. In: Knorr-Cetina $\mathrm{K}$ and Cicourel AV (eds) Advances in social theory and methodology: toward an integration of micro-and macro-sociologies. London: Routledge, pp. 277-303.

Campbell C (2009) Distinguishing the power of agency from agentic power: a note on Weber and the 'black box' of personal agency. Sociological Theory 27(4): 407-418.

Cangiano A and Walsh K (2014) Recruitment processes and immigration regulations: the disjointed pathways to employing migrant carers in ageing societies. Work, Employment \& Society 28(3): 372-389.

Carter J (2000) New public management and equal opportunities in the NHS. Critical Social Policy 20(1): 61-83. 
Dahle R and Seeberg ML (2013) Does she speak Norwegian? Nordic Journal of Migration Research 3(2): 82-90.

Emirbayer M (1997) Manifesto for a relational sociology. American Journal of Sociology 103(2): 281-317.

Eteläpelto A, Vähäsantanen K, Hökkä P and Paloniemi S (2013) What is agency? Conceptualizing professional agency at work. Educational Research Review 10: $45^{-65}$.

Fuchs S (2001) Beyond agency. Sociological Theory 19(1): 24-40.

Gallo E and Scrinzi F (2016) Outsourcing elderly care to migrant workers: the impact of gender and class on the experience of male employers. Sociology 50(2): 366-388.

Garfinkel H (1967) Studies in ethnomethodology. Englewood Cliffs, NJ: Prentice-Hall.

Giddens A (1984) The constitution of society: outline of the theory of structuration. Berkeley: University of California Press.

Goffman E (1955) On face-work: an analysis of ritual elements in social interaction. Psychiatry 18(3): 213-231.

Goffman E (1959) The presentation of self in everyday life. Harmondsworth: Penguin.

Hacking I (2004) Between Michel Foucault and Erving Goffman: between discourse in the abstract and face-to-face interaction. Economy and society 33(3): 277-302.

Harré R (2009) The siren song of substantivalism. Journal for the Theory of Social Behaviour 39(4): 466-473.

Hellgren Z (2015) Markets, regimes, and the role of stakeholders: explaining precariousness of migrant domestic/care workers in different institutional frameworks. Social Politics: International Studies in Gender, State \& Society 22(2): 220-241. 
Hughes EC (1984) The sociological eye: selected papers. New Brunswick: Transaction books.

Kröger T, Van Aerschot L and Puthenparambil JM (2018) Hoivatyö muutoksessa. Suomalainen vanhustyö pohjoismaisessa vertailussa. Jyväskylä: University of Jyväskylä.

Lamont M and Swidler A (2014) Methodological pluralism and the possibilities and limits of interviewing. Qualitative Sociology 37(2): 153-171.

May V (2018) Personal communication.

McGovern P (2007) Immigration, labour markets and employment relations: problems and prospects. British Journal of industrial relations 45(2): 217-235.

Meyer JW and Jepperson RL (2000) The 'actors' of modern society: the cultural construction of social agency. Sociological Theory 18(1): 100-120.

Misra J, Woodring J and Merz SN (2006) The globalization of care work: neoliberal economic restructuring and migration policy. Globalizations 3(3): 317-332.

Mützel S (2009) Networks as culturally constituted processes: a comparison of relational sociology and actor-network theory. Current Sociology 57(6): 871887.

Nordberg C (2016) Outsourcing equality. Nordic Journal of Working Life Studies 6(3): 101-118.

Nikander P (2012) Interviews as discourse data. In: Gubrium JF, Holstein JA, Mackinney-Marvasti K and Marvasti A (eds) Handbook of Interview Research (second edition). London: Sage, pp. 397-413.

Niska M (2015) Who is serving whom? An agency-for perspective on enterprise promotion in rural Finland. Helsinki: University of Helsinki.

Näre L (2012) Hoivatyön glokaaleilla markkinoilla: filippiiniläisten sairaanhoitajien rekrytointi Suomeen jälkikolonialistisena käytäntönä. Sosiologia 49(3): 206-221. 
Näre L (2013) Ideal workers and suspects: employers' politics of recognition and the migrant division of care labour in Finland. Nordic Journal of Migration Research 3(2): 72-81.

Näre L and Nordberg C (2016) Neoliberal postcolonialism in the media: constructing Filipino nurse subjects in Finland. European journal of cultural studies 19(1): 16-32.

Olakivi A (2013) 'In case you can speak Finnish, there's no problem.' Reconstructing problematic identity-positions in migrant care workers' organisational discourse. Nordic Journal of Migration Research 3(2): 91-99.

Olakivi A (2018) The relational construction of occupational agency. Performing professional and enterprising selves in diversifying care work. Helsinki: University of Helsinki.

Olakivi A and Niska M (2016) Constructing homelikeness: migrant caregivers and the politics of 'activation' in public care provision in Finland. In: Walsh $\mathrm{K}$ and Näre L (eds) Transnational migration and home in older age. New York: Routledge, pp. 215-226.

Olakivi A and Niska M (2017) Rethinking managerialism in professional work: from competing logics to overlapping discourses. Journal of Professions and Organization 4(1): 20-35.

Reynolds J, Wetherell M and Taylor S (2007) Choice and chance: negotiating agency in narratives of singleness. The Sociological Review 55(2): 331-351.

Roseneil S and Ketokivi K (2016) Relational persons and relational processes: developing the notion of relationality for the sociology of personal life. Sociology 50(1): 143-159.

Shapiro SP (2005) Agency theory. Annual Review of Sociology 31: 263-284.

Shutes I and Walsh K (2012) Negotiating user preferences, discrimination, and demand for migrant labour in long-term care. Social Politics: International Studies in Gender, State \& Society 19(1): 78-104. 
Statistics Finland (2016) Statistics available on request from the Statistics Finland and the author.

Sulkunen P (2010) Agency and power: the contractual illusion. European Journal of Cultural Studies 13(4): 495-510.

Torres S (2017) Fobbing care work unto "the other"-what daily press reporting shows. Sociologisk forskning 54(4): 319-322.

Waldinger R and Lichter MI (2003) How the other half works: Immigration and the social organization of labor. Berkeley: University of California Press.

Williams F (2018) Care: Intersections of scales, inequalities and crises. Current Sociology 66(4): 547-561.

Whittle A and Mueller F (2016) Accounting for the banking crisis: repertoires of agency and structure. Critical Discourse Studies 13(1): 20-40.

Wrede S (2010) Nursing: globalization of a female-gendered profession. In: Kuhlmann E and Annandale E (eds) The Palgrave handbook of gender and healthcare. London: Palgrave Macmillan UK, pp. 437-453.

Zanoni P and Janssens M (2004) Deconstructing difference: the rhetoric of human resource managers' diversity discourses. Organization Studies 25(1): $55^{-74}$. 